\title{
Analysis of Total Phenol from Sentul Fruit Extraction (Sandoricum koetjape Merr.)
}

\author{
Faizul Bayani \\ Pharmacy Study Program, Universitas Qamarul Huda Badaruddin Bagu, J1. H. \\ Badaruddin Desa Bagu 83562, Indonesia \\ Corresponding Author Email: faizulbayani@uniqhba.ac.id
}

\begin{abstract}
Article History
Received: April 2021

Accepted: May 2021

Published: June 2021

\section{Key Words}

Sandoricum koetjape

Merr; Total Phenol;

Folin-Ciocalteu Method
\end{abstract}

How to cite this article?

\begin{abstract}
Studies on Sentul fruit have identified the presence of phenolic compounds in the flesh and have not yet analyzed the total phenolic content. This encourages research to conduct further analysis of the total phenol of Sentul fruit, this is to optimize the value of its benefits, especially in the health sector so that its use can be increased as phytopharmacology drugs. Extensive laboratory studies were carried out with sample preparation and qualitative analysis of total phenol. Determination of the total phenol content contained in the sample extract was carried out based on the Folin-Ciocalteu method. In the end, in this study we can conclude that the total phenolic content of the crude extract of ripe Sentul fruit pulp showed positive results in various sample treatments. Further results are explained in this article.
\end{abstract}

Bayani, F. (2021). Analysis of Total Phenol from Sentul Fruit Extraction (Sandoricum koetjape Merr.). Lensa: Jurnal Kependidikan Fisika, 9(1), 58-64. doi:https://doi.org/10.33394/j-1kf.v9i1.4263

\section{INTRODUCTION}

Indonesia has many types of fruit trees, both domesticated and still growing naturally, or are in a transitional stage between the two. Sentul or Kecapi (Sandoricum koetjape Burm. $f$. Merr) is one of the fruit-producing plants that has been neglected by the community. Sentul is a garden plant in the community, widely cultivated, but it needs attention so that it does not become rare, because some of the younger generation, especially in big cities, do not pay attention to this species. The benefits and uses of Sentul include edible fruit, the wood is widely used for household appliances, and many other benefits (Nugroho \& Pudjawati, 2019). The growth of this plant is widely found in Asia, and recently explored its benefits as a medicinal plant, so it became popular and experienced naturalization (Milow et al., 2014).

Sentul fruit is round, slightly flattened, with a normal diameter of 5-6 cm, yellow or reddish when ripe, and has soft, velvety hair. The outer flesh of the fruit is thick and hard, fused to the skin, reddish, slightly sour; the inner flesh of the fruit is soft, juicy, attached to the seeds, white, and has a sour to sweet taste. Number of seeds 2-5 grains, large, slightly flattened oval, shiny reddish brown; red seeds. The color of fruits and fruit products can be attributed to the content of phenolic compounds (Kartika, 2016), even the leaves, stems and roots of the Sentul tree contain saponins, flavonoids, and polyphenols. Traditionally, the bark powder is efficacious for the treatment of roundworms. The roots and leaves are efficacious as a vaginal discharge medicine, heartburn medicine, cough medicine, fever reducer, bloating medicine, stomach pain, diarrhea, and to strengthen the body of women after childbirth. Previous studies reported that antibacterial bioactive compounds that could inhibit the growth of Micrococcus luteus and Eschericia coli bacteria were found in sentul leaf extract (70\% ethanol) (Swantara, 2009). 
Preliminary research on the chemical content of the skin and flesh of young Sentul fruit has identified the presence of phenolic compounds and alkaloids in the three extracts: petroleum ether, chloroform, and methanol (Warsinah et al., 2015). Phenolic compounds have considerable benefits, mainly as antioxidant compounds. Regarding their antioxidant activity, phenolic compounds and fruit extracts have been reported to have positive effects on the prevention of cancer, cardiovascular disease, immune system, microbial infections, neurogenerative diseases, and viral/inflammatory infections (Panche et al., 2016; Shahidi \& Ambigaipalan, 2015). The results of epidemiological studies also show that consumption of fruits and vegetables with high content of phenolic compounds that function as antioxidants such as vitamins $\mathrm{C}, \mathrm{A}$, and $\mathrm{E}$, as well as polyphenolic compounds can suppress the occurrence of coronary heart disease, diabetes, hypertension, stroke, cancer, and Alzheimer's disease (Boccellino \& D'Angelo, 2020).

It is quite interesting that when the Sentul fruit flesh is sliced, the part immediately turns brown. This phenomenon is relevant to previous studies (Moon et al., 2020) that enzymatic browning reactions can occur during ripening or due to interference (slicing) of fruits and vegetables containing phenolic compounds. This browning reaction is related to the oxidation of phenolic compounds with the catalyst of the polyphenol oxidase enzyme to produce brown colored compounds.

Preliminary research on Sentul fruit has only identified the presence of phenolic compounds in young fruit flesh and has not yet analyzed the total phenolic content. This encourages researchers to conduct further analysis of the total phenol of Sentul fruit with the aim of optimizing the value of its benefits, especially in the health sector so that its use can be increased as phytopharmaca drugs.

\section{METHOD}

\section{Sample preparation}

The tools used in this research are glassware commonly used in laboratories, incubators, evaporators, centrifuges, blenders and a set of spectrophotometers. While the materials used were Sentul fruit, methanol, $\mathrm{Na}_{2} \mathrm{CO}_{3}$ solution, Folin ciocalteu reagent, $\mathrm{FeCl}_{3}$ solution, Millon's reagent, phenol solution, ion-free water, and distilled water. Furthermore, in the preparation of sample sample extracts, Sentul fruits are picked directly from plantations in the Lombok area, West Nusa Tenggara Province - Indonesia. Sentul fruit pulp extract was prepared through three types of treatment.

(1) Preparation of Sample A. Sample A was Sentul fruit flesh which was processed by sun drying and maceration using $80 \%$ methanol as a solvent in a ratio of 1 gram: $10 \mathrm{~mL}$. A total of 4,500 grams of skin and skin of fresh Sentul fruit that have been sliced are dried in the sun for 20 hours 16 minutes for 3 days with an average drying rate of 6 hours 45 minutes per day until the water content is reduced by $80.89 \%$. The results of the drying are blended up to $2 \mathrm{~mm}$ in size. 100 grams of the blended sample was macerated with $1000 \mathrm{~mL}$ of $80 \%$ methanol for $3 \times 24$ hours to ensure the optimal extraction process. The $80 \%$ methanol-sample solution was filtered with Whatman filter paper then the solvent was evaporated with an evaporator at a temperature of 60 $-65^{\circ} \mathrm{C}$. The thick extract obtained was then left in an air-conditioned room for 24 hours. The thick extract is stored in the refrigerator until the time of testing is carried out.

(2) Preparation of Sample B. Sample B was Sentul fruit flesh without sun drying and macerated using $80 \%$ methanol solvent with a ratio of 1 gram: $10 \mathrm{~mL}$. Samples were prepared by slicing fresh Sentul fruit into small pieces and immediately immersed in $80 \%$ methanol to prevent direct oxidation. The sample was then blended and 75 grams of the sample was macerated with $750 \mathrm{~mL}$ of $80 \%$ methanol for $2 \times 24$ hours until 
optimal extraction. The methanol-sample extract was filtered with whatman filter paper and then evaporated to remove the solvent from the sample. The thick extract obtained was then left in an air-conditioned room for 24 hours. The viscous extract is stored in the refrigerator until the measurement time is carried out.

(3) Preparation of Sample C. Sample C was Sentul fruit flesh which was processed by sun drying and extracted using a Soxhlet extractor with $80 \%$ methanol. A total of 75 grams of the results of the blender sample A in the form of powder (fine grains) were put into Soxhlet. $250 \mathrm{~mL}$ of $80 \%$ methanol was used as the solvent. The extraction process was carried out for 7 cycles to ensure optimal extraction. The methanol-sample extract obtained was then evaporated to evaporate the solvent and a thick extract of the sample was obtained. The thick extract of the sample was left for 24 hours in an airconditioned room. The viscous extract was stored in the refrigerator until the time of testing.

\section{Qualitative Analysis of Phenol}

This qualitative analysis aims to determine whether Sentul fruit extract contains phenolic compounds with specific color change indicators. This qualitative analysis used Millon's test and $\mathrm{FeCl}_{3}$, namely; a) Millon's test: A total of $5 \mathrm{~mL}$ of sample solution was added to $1 \mathrm{~mL}$ of Millon's reagent, observed the color changes that occurred. The formation of a white precipitate which when heated red means a positive reaction indicating the presence of phenolic compounds; b) Qualitative Test of Phenol with Iron (III) chloride: The classic way to detect simple phenolic compounds is to add $1 \mathrm{~mL}$ of a $1 \%$ solution of $\mathrm{FeCl}_{3}$ (Iron (III) chloride) in water or ethanol with $5 \mathrm{~mL}$ of extract solution, which gives a green color, red, purple, blue, strong black, dusky green, or dusky blue.

\section{RESULTS AND DISCUSSION}

Qualitative tests of phenolic compounds were carried out with 2 (two) types of reactions, namely using Millon's reagent and $\mathrm{FeCl}_{3}$ reagent. Qualitative test of phenolic compounds on sample extracts using Millon's reagent showed a positive reaction. This is indicated by a change in the color of the solution, namely the formation of a white precipitate which after being heated to red, the test results appear clearer than the sample diluted to 20,000 ppm. The test results relevant to the qualitative identification of phenolic compounds with Millon's reagent have been reported (Sapkota, 2020). Millon's reagent is a solution of mercury and mercury nitrate in nitric acid. Basically, Millon's reaction is positive to detect the presence of phenolic compounds, due to the formation of mercury compounds with colored hydroxyphenyl groups. The general reaction that occurs between phenol and Millon's reagent has been described as follows. 


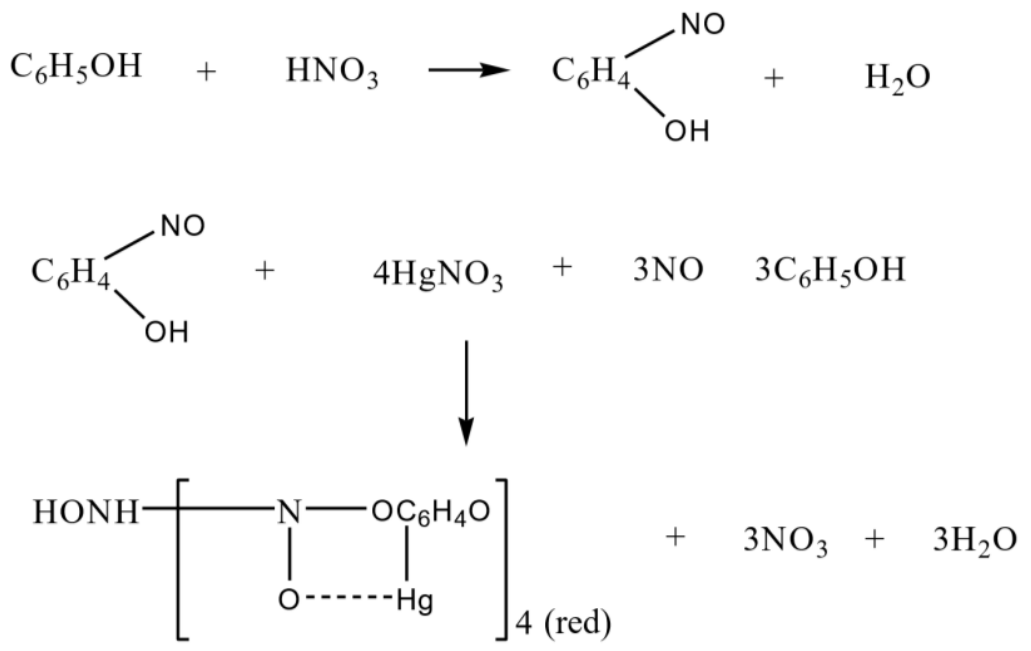

Figure 1. General reaction steps of Millon's reagent with phenol.

The next qualitative test of phenolic compounds used a $1 \%$ solution of Iron (III) chloride. The reaction between $\mathrm{FeCl}_{3}$ and phenolic compounds will give a change in the color of the solution to a strong green, red, purple, blue, or black (Kurniawan \& Wardany, 2021) which means that the tested sample contains a phenol group. The reaction of the sample extract with this reagent showed positive results, where the sample extract with a dilution of up to $1,000 \mathrm{ppm}$ after reacting gave a change in the color of the solution to light green and with the sample diluted up to $20,000 \mathrm{ppm}$ the color of the solution changed to blackish green and a black precipitate was formed. This indicates that the sample extract contains phenolic compounds. More specifically, the discoloration to blackish green indicates that the sample contains catechol tannins (which are phenol derivative compounds). The general reaction that occurs between phenol and $\mathrm{FeCl} 3$ reagent is described as follows.

$$
\mathrm{FeCl}_{3} 1 \%+3 \mathrm{PhOH} \longrightarrow \mathrm{Fe}(\mathrm{O}-\mathrm{Ph})_{3} \text { (black) }+3 \mathrm{HCL}
$$

Based on these results, it can be estimated that the black precipitate formed in this reaction is a compound of $\mathrm{Fe}(\mathrm{O}-\mathrm{Ph})_{3}$. Determination of the total phenol content in the sample extract was carried out based on the Folin-Ciocalteu method (Salim et al., 2020) with a few modification. The Folin-Ciocalteu method is the most popular method used by researchers to determine the total phenol content of a food or fruit. This method cannot be used to determine specific types of phenolic compounds, but will only detect all types of phenolic compounds contained in plant extracts.

The positive reaction between the Folin-Ciocalteu reagent with the standard solution and the sample extract in this study qualitatively indicated a change in the color of the solution to blue. The principle of the Folin-Ciocalteu method is the ability to reduce the phenol group to the Folin-Ciocalteu reagent. The reaction of reduction and oxidation of phenolic ions takes place under basic conditions, therefore the addition of a $2 \% \mathrm{Na}_{2} \mathrm{CO}_{3}$ solution is an attempt to condition the basicity of the solution system. The blue color formed after the reaction occurred was due to the reduction of the phosphotungstatephosphomolybdenum complex compound (Folin-Ciocalteu reagent) by phenolic ions in standard solutions and sample extracts (Saptasari, 2019). The blue color formed gets darker with increasing concentration of phenolic compounds.

Determination of the total phenolic content in the sample extract was carried out by measuring the absorbance of the three types of sample extracts $(\mathrm{A}, \mathrm{B}$, and $\mathrm{C})$ which were 
diluted to $500 \mathrm{ppm}$ at a maximum wavelength of $720 \mathrm{~nm}$ with a UV-Vis spectrophotometer. From the results, it is known that the extract of sample B $(12.86 \%)$ has the highest total phenolic content, then followed by sample $\mathrm{C}(9.36 \%)$ and sample A $(6.9 \%)$. This difference in results is of course greatly influenced by the conditions of the sample extraction process, including; a) the heating temperature carried out on samples A and $\mathrm{C}$, which during the sun drying process can cause damage to the structure of the phenolic compounds they contain as well as further oxidation processes to form new compounds that cannot function as antioxidants, so that the total phenol extract of samples $\mathrm{A}$ and $\mathrm{C}$ is measured. Lower than sample $\mathrm{B}$ extract without drying; $\mathrm{b}$ ) the size (diameter) of the extracted sample, in this case the extract of sample $\mathrm{C}$ had a higher total phenolic content than the extract of sample A because the diameter of sample $\mathrm{C}$ was smaller (fine powder) than sample A with a diameter of $2 \mathrm{~mm}$.

The time and length of the extraction process also affect the uptake of phenolic compounds from plant parts. In addition, heating in the extraction process with a Soxhlet extractor, and heating during solvent evaporation with an evaporator can affect the measured total phenol content where phenolic compounds can easily undergo oxidation reactions either directly due to heating and oxygen contact (auto-oxidation) or with oxygen. The help of enzymes (enzymatic oxidation). One example is the auto-oxidation of catechol as follows.

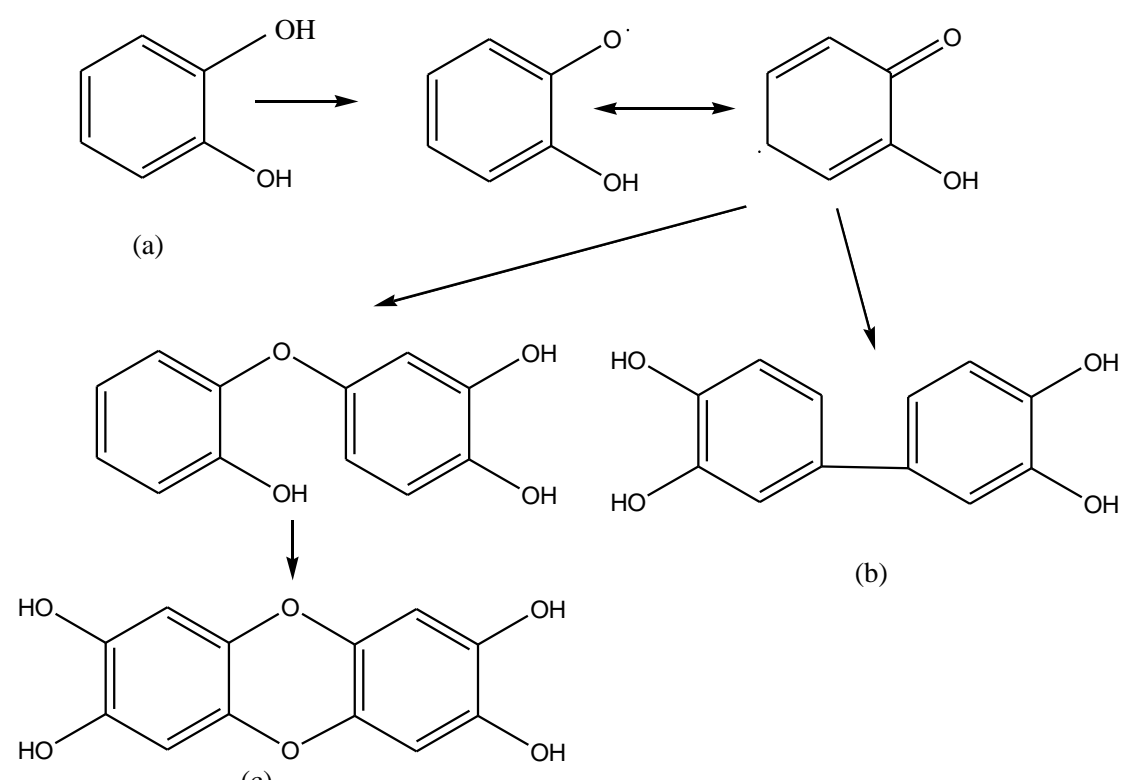

(c)

Figure 2. Auto-oxidation of catechol can form different dimers.

Phenolic compounds can easily undergo auto-oxidation reactions because they have an aromatic ring. The radicals generated from this reaction can react with other radicals to form a dimer and because of their electron delocalization ability, several phenolic derivative structures can be formed depending on the location of the electron radicals during the reaction. Figure 2 shows that catechol radicals (a) react further to form tetrahydroxyl-biphenyl (b) and quinine (c). This brief description shows that although the sample phenolic compounds undergo auto-oxidation reactions, it cannot be concluded that the samples will be completely damaged, thus affecting the measurement results for the total phenolic content but depending on the final results of the compounds produced, whether they can still be oxidized by Folin-Agent reagent Ciocalteu and DPPH or not. 


\section{CONCLUSION}

Based on the results of the study, it can be concluded that the viscous extract of the sample by sun drying and maceration (A) was $19.97 \mathrm{gr} / 100$ gr sample (19.97\%), the sample without sun drying and directly macerated (B) was $16.37 \mathrm{gr} / 75 \mathrm{gr}$ sample (21.83\%), and sample with sun drying and Soxhlet extractor (C) $11.18 \mathrm{gr} / 75 \mathrm{gr}$ sample (14.91\%). The results of the qualitative test using Millon's reagent and $1 \% \mathrm{FeCl} 3$ reagent can be concluded that the extracts of samples $\mathrm{A}, \mathrm{B}$, and $\mathrm{C}$ contain phenolic compounds. The total levels of phenolic compounds in the extracts of samples $\mathrm{A}, \mathrm{B}$, and $\mathrm{C}$ were $6.9 \%$, $12.86 \%$, and $9.36 \%$, respectively.

\section{RECOMMENDATION}

The results of the analysis of the total phenolic content of the crude extract (crude extract) of ripe Sentul fruit flesh in this study showed positive results and was high enough so that further research was needed on the total phenolic content of pure isolates of specific phenolic compounds contained in the extract of Sentul fruit flesh and from other parts such as leaves, bark, stems, roots, and seeds.

\section{REFERENCES}

Boccellino, M., \& D'Angelo, S. (2020). Anti-Obesity Effects of Polyphenol Intake: Current Status and Future Possibilities. International Journal of Molecular Sciences, 21(16), 5642. https://doi.org/10.3390/ijms21165642

Kartika, R. (2016). Pengaruh Pemberian Ekstrak Etanol Daun Kecapi (Sandoricum koetjape (Burm.f.) Merr.) Terhadap Penurunan Kadar Kolesterol Total pada Mencit Jantan (Mus musculus). JURNAL KIMIA MULAWARMAN, 13(2). http://jurnal.kimia.fmipa.unmul.ac.id/index.php/JKM/article/view/200

Kurniawan, M. F., \& Wardany, H. N. K. (2021). Hepatoprotective Activity of Ethanol Extract of Figs Leaves (Ficus carica L.) with SGOT \& SGPT Parameters in Sprague Dawley Female Rats Induced by Paracetamol. Jurnal Farmasi Galenika (Galenika Journal of Pharmacy) (e-Journal), 7(2), 110-119. https://doi.org/10.22487/j24428744.2021.v7.i2.15443

Milow, P., Malek, S. B., Edo, J., \& Ong, H.-C. (2014). Malaysian Species of Plants with Edible Fruits or Seeds and Their Valuation. International Journal of Fruit Science, 14(1), 1-27. https://doi.org/10.1080/15538362.2013.801698

Moon, K. M., Kwon, E.-B., Lee, B., \& Kim, C. Y. (2020). Recent Trends in Controlling the Enzymatic Browning of Fruit and Vegetable Products. Molecules, 25(12), 2754. https://doi.org/10.3390/molecules25122754

Nugroho, A. B. H., \& Pudjawati, E. D. (2019). Respon Pertumbuhan Biji Kecapi (Sandoricum koetjape (Burm.f.) Merr) Terhadap Pemberian ZPT IBA dan BAP Secara Invitro. 02(6), 9.

Panche, A. N., Diwan, A. D., \& Chandra, S. R. (2016). Flavonoids: An overview. Journal of Nutritional Science, 5, e47. https://doi.org/10.1017/jns.2016.41

Salim, S. A., Saputri, F. A., Saptarini, N. M., \& Levita, J. (2020). Kelebihan dan Keterbatasan Pereaksi Folin-Ciocalteu Dalam Penentuan Kadar Fenol Total Pada Tanaman. Farmaka, 18(1), 46-57. https://doi.org/10.24198/jf.v18i1.21909

Sapkota, A. (2020, November 24). Millon's Test-Definition, Principle, Procedure, Result, Uses. Microbe Notes. https://microbenotes.com/millons-test/

Saptasari, T. (2019). Kadar Fenolik Dan Aktivitas Antioksidan Ekstrak Etanol Rumput Laut Coklat (Padina australis). Fitofarmaka, 9(1), 1-8.

Shahidi, F., \& Ambigaipalan, P. (2015). Phenolics and polyphenolics in foods, beverages and spices: Antioxidant activity and health effects - A review. Journal of Functional Foods, 18, 820-897. https://doi.org/10.1016/j.jff.2015.06.018 
Swantara, I. M. D. (2009). Identifikasi Senyawa Antibakteri. JURNAL KIMIA, 3(2), 8.

Warsinah, W., Kusumawati, E., \& Sunarto, S. (2015). Identification of Compound Antifungi of Sandoricum koetjape. Stem and Activity to Candida albicans. Majalah Obat Tradisional, 16(3), 170-178. https://doi.org/10.22146/tradmedj.8055 